\title{
Optimization and Prediction of the Drying and Quality of Turnip Slices by Convective-Infrared Dryer under Various Pretreatments by RSM and ANFIS Methods
}

\author{
Ebrahim Taghinezhad ${ }^{1, *(D)}$, Mohammad Kaveh ${ }^{2}\left(\mathbb{D}\right.$ and Antoni Szumny ${ }^{3}$ (D) \\ 1 Department of Agricultural Technology Engineering, Moghan College of Agriculture and Natural Resources, \\ University of Mohaghegh Ardabili, Ardabil 56199-11367, Iran \\ 2 Faculty of Agriculture and Natural Resources, University of Mohaghegh Ardabili, Ardabil 56199-11367, Iran; \\ sirwankaweh@uma.ac.ir \\ 3 Department of Chemistry, Wroclaw University of Environmental and Life Science, CK Norwida 25, \\ 50-375 Wrocław, Poland; antoni.szumny@upwr.edu.pl \\ * Correspondence: e.taghinezhad@uma.ac.ir; Tel.: +98-45-3271-5408
}

Citation: Taghinezhad, E.; Kaveh, M.; Szumny, A. Optimization and Prediction of the Drying and Quality of Turnip Slices by Convective-Infrared Dryer under Various Pretreatments by RSM and ANFIS Methods. Foods 2021, 10, 284. https://doi.org/10.3390/ foods10020284

Academic Editor: Sze Ying Leong Received: 25 December 2020

Accepted: 18 January 2021

Published: 31 January 2021

Publisher's Note: MDPI stays neutral with regard to jurisdictional claims in published maps and institutional affiliations.

Copyright: (c) 2021 by the authors. Licensee MDPI, Basel, Switzerland. This article is an open access article distributed under the terms and conditions of the Creative Commons Attribution (CC BY) license (https:/ / creativecommons.org/licenses/by/ $4.0 /)$.

\begin{abstract}
Drying can prolong the shelf life of a product by reducing microbial activities while facilitating its transportation and storage by decreasing the product weight and volume. The quality factors of the drying process are among the important issues in the drying of food and agricultural products. In this study, the effects of several independent variables such as the temperature of the drying air $\left(50,60\right.$, and $\left.70{ }^{\circ} \mathrm{C}\right)$ and the thickness of the samples $(2,4$, and $6 \mathrm{~mm})$ were studied on the response variables including the quality indices (color difference and shrinkage) and drying factors (drying time, effective moisture diffusivity coefficient, specific energy consumption (SEC), energy efficiency and dryer efficiency) of the turnip slices dried by a hybrid convective-infrared (HCIR) dryer. Before drying, the samples were treated by three pretreatments: microwave (360 W for $2.5 \mathrm{~min}$ ), ultrasonic (at $30{ }^{\circ} \mathrm{C}$ for $10 \mathrm{~min}$ ) and blanching (at $90{ }^{\circ} \mathrm{C}$ for $2 \mathrm{~min}$ ). The statistical analyses of the data and optimization of the drying process were achieved by the response surface method (RSM) and the response variables were predicted by the adaptive neuro-fuzzy inference system (ANFIS) model. The results indicated that an increase in the dryer temperature and a decline in the thickness of the sample can enhance the evaporation rate of the samples which will decrease the drying time (40-20 min), SEC (from 168.98 to $21.57 \mathrm{MJ} / \mathrm{kg}$ ), color difference (from 50.59 to 15.38 ) and shrinkage (from $67.84 \%$ to $24.28 \%$ ) while increasing the effective moisture diffusivity coefficient (from $1.007 \times 10^{-9}$ to $8.11 \times 10^{-9} \mathrm{~m}^{2} / \mathrm{s}$ ), energy efficiency (from $0.89 \%$ to $15.23 \%$ ) and dryer efficiency (from $2.11 \%$ to $21.2 \%$ ). Compared to ultrasonic and blanching, microwave pretreatment increased the energy and drying efficiency; while the variations in the color and shrinkage were the lowest in the ultrasonic pretreatment. The optimal condition involved the temperature of $70{ }^{\circ} \mathrm{C}$ and sample thickness of $2 \mathrm{~mm}$ with the desirability above 0.89 . The ANFIS model also managed to predict the response variables with $R^{2}>0.96$.
\end{abstract}

Keywords: blanching; drying; efficiency; energy; microwave; ultrasound

\section{Introduction}

The turnip has been long used in the human diet due to its high vitamin and mineral contents. Its use dates back to the prehistoric era. The turnip is cultivated in Europe and Iran, especially in cold regions [1]. Recently, the turnip has attracted the attention of consumers due to its high antioxidant content and anti-inflammatory, anti-diabetes, and anticancer features, in addition to its glucosinolates, flavonoids, and phenylpropanoid contents [2].

During the drying process, the moisture content of the product will be declined by heat and simultaneous mass transfer between the surroundings and sample surfaces. This 
process can be used as one of the important storage methods to prolong the shelf life of the product, reduce its transportation costs and minimize its packing requirements [3]. Drying can also prevent the spoilage and wastes of the crops after their harvest [4].

Among various industrial commercial dryers, convective dryers have found extensive applications in diverse industries including food and agriculture. This method, however, suffers from serious problems such as long processing time, low efficiency, high energy consumption rate, and declining quality of the product [5]. To resolve these issues, novel technologies such as hybrid dryers with the use of pretreatments can be employed [6].

The infrared method is one of the recent approaches used in the drying of food products, this method often applied in combination with convective methods and its goal is to accelerate the process of drying, reduce the energy consumption and improve the quality of the final product [7]; for instance, a hybrid convective-infrared (HCIR) dryer was used to dry blackberry [7,8] and potato [9]. Today, various pretreatments have been employed to reduce the drying time and improve the quality of the crops. Using these pretreatments, it is possible to reduce some of the unwanted variations such as textural and color changes [10]. So far, various pretreatments have been employed in the drying industry. Ultrasound and blanching pretreatments were used in a hybrid microwave-convective dryer to dry parsley leaves [11]. In another study, osmotic and ultrasound pretreatment were employed for drying strawberries under convective drying [12]. Ethanol and ultrasound were used as a pretreatment to dry potatoes using an infrared (IR) drying approach [13], citric acid and blanching were used to dry cauliflower using the convective dryer [10]. Other studies have been conducted by various dryers using different pretreatments to dry diverse crops for instance, blackberry [14], raspberries [15], Mirabelle plum [16], cranberry snacks [17], carrot discs [5], and cabbage [18]. These studies indicated that the use of these pretreatments can increase the effective moisture diffusion coefficient while reducing the drying time and specific energy consumption (SEC); hence improving the quality of the dried products. To the best of our knowledge, no study has addressed the influence of various pretreatments on the drying process of turnip slices using a hybrid convective-infrared (HCIR) dryer.

The relationship between the independent and dependent variables of the drying process is of crucial significance. Although some of the numerical methods have managed to some extent to resolve the complexity of the non-linear behavior. Due to the limitations of these methods, researchers have focused on other statistical methods such as adaptive neuro-fuzzy inference system (ANFIS) and response surface methods [19]. The neural-fuzzy deductive systems simultaneously exploit the merits of the artificial neural network and fuzzy logic. This method can be used to approximate the non-linear relationship between the inputs and outputs and has shown bright capabilities in the training, construction, and classification stages [20]. The response surface method (RSM) is a series of mathematical and statistical methods to model and analyze problems in which the response variable is under the influence of several independent variables. This method is aimed to optimize the response variables [21]. In RSM optimization, input variables are defined as the independent ones and their influence on the response (dependent) variable is explored. Numerous researchers have used RSM and ANFIS to model and optimize the quality and drying process of various crops including okra [22], quince [23], yacon [24], lavender leaves [25], and rough rice [26] for RSM and blackberries [8], almond [20], and yam slices [27] using the ANFIS method.

Regarding the importance of turnip in the human diet, its storage at high quality is of crucial significance. Previous studies have shown that no work has addressed the use of RSM and ANFIS to optimize and predict the quality and drying process of the turnip slices using HCIR dryers. In this regard, the aim of the present study is to model and optimize the effects of independent variables (slice thickness, temperature) on the dependent variables (drying time, effective moisture diffusion coefficient, SEC, energy efficiency, drying efficiency, shrinkage, and color) in drying turnip slices. In this research, turnip slices at the thicknesses of 2, 4, and $6 \mathrm{~mm}$ were dried by an HCIR dryer after various pretreatments (microwave, ultrasound, and blanching). 


\section{Materials and Methods}

\subsection{Turnip Preparation}

Fresh turnips were provided from ParsAbad City, Ardebil province (Iran). The samples were kept in a refrigerator at $+4{ }^{\circ} \mathrm{C}$. Prior to the experiments, the turnip samples were left at room temperature for $1 \mathrm{~h}$. The initial moisture of the samples was determined at $10.23 \%$ (d.b.) using an oven (Memmert company, UFB50 model, Schwabach Germany) at $70{ }^{\circ} \mathrm{C}$ for $24 \mathrm{~h}$.

\subsection{Pretreatments}

The pretreatments were carried out on the turnip samples before the drying process as follows:

\subsubsection{Blanching}

For blanching pretreatment, a warm water bath (Memmert, WNB 14, Schwabach, Germany) was used. This bath had a maximum temperature of $120^{\circ} \mathrm{C}$ and an accuracy of $\pm 0.1^{\circ} \mathrm{C}$. The samples were placed in a warm bath at $90^{\circ} \mathrm{C}$ for $2 \mathrm{~min}$ [17].

\subsubsection{Ultrasound Pre-Treatment}

Ultrasound pretreatment was carried out using an ultrasonic bath (Parsonic, 7500s, Tehran, Iran) at the frequency of $28 \mathrm{kHz}$ and power of $70 \mathrm{~W}$ regarding the constant frequency of the bath, turnip samples were immersed in distilled water at $30{ }^{\circ} \mathrm{C}$ and exposed to ultrasound waves for $10 \mathrm{~min}$ [28].

\subsubsection{Microwave Pre-Treatment}

A domestic microwave oven (Panasonic NN-C2002W, Tokyo, Japan) at the frequency of $50 \mathrm{~Hz}$ and maximum heating power of $1000 \mathrm{~W}$ (with the capability of tuning the power at $90,180,360,600$, and $900 \mathrm{~W}$ ) was employed for microwave pretreatment of the samples, the pretreatment was carried out at the power of $360 \mathrm{~W}$ for $2.5 \mathrm{~min}$ [29].

\subsection{Hybrid Convective-Infrared (HCIR) Dryer}

After pretreatments, the drying process was conducted using an HCIR dryer (GC 400 model, company Grouc, Tehran, Iran). This dryer includes two Infrared (IR) lamps (Philips model, Flemish, Belgium) working at the power of $500 \mathrm{~W}$ which are installed at the upper part of the drying chamber at the height of $30 \mathrm{~cm}$ the dryer has a centrifuge blower to blow hot air parallel to the substrate. To create the input air, a centrifuge fan equipped with an inverter (Vincker VSD2, ABB Co., Taipei, Taiwan) was employed. The input air speed was set at $1 \mathrm{~m} / \mathrm{s}$. The samples were placed on a meshed container on a digital balance (AND, GF-6000, A\&D Company Ltd., Tokyo, Japan) at the accuracy of $0.01 \mathrm{~g}$ placed beneath the channel. The turnips were cut into 2, 4 and $6 \mathrm{~mm}$ thick pieces and pretreated using blanching, microwave and ultrasonic methods. The samples were then dried with a HCIR dryer at three temperature levels $\left(50,60\right.$ and $\left.70{ }^{\circ} \mathrm{C}\right)$. Before the tests, the dryer was operated for $15 \mathrm{~min}$ to reach a constant temperature and air speed. In each test, one layer of $40 \mathrm{~g}$ turnip slice was placed on the dryer tray. During the drying process, the mean temperature and air humidity were $20 \pm 4{ }^{\circ} \mathrm{C}$ and $15 \pm 5 \%$, respectively.

\subsection{Moisture Ratio}

Moisture ratio of the hybrid convective-infrared (HCIR)-dried turnip slices was determined by Equation (1) [1]:

$$
M R=\frac{M_{t}-M_{e}}{M_{b}-M_{e}}
$$




\subsection{Effective Moisture Diffusivity}

Fick's law, Equation (2), can describe the moisture transport in the descending stage of the drying process [30]:

$$
\frac{\partial X}{\partial t}=D_{e f f} \frac{\partial^{2} X}{\partial x^{2}}
$$

The second Fick's law is related to the mass diffusivity during the descending phase of the drying process, using appropriate boundary conditions, it is possible to solve the Fick's equation for various geometries. For a thin layer, the Fick equation can be solved by Equation (3) [31]:

$$
M R=\frac{8}{\pi^{2}} \sum_{n=1}^{\infty} \frac{1}{(2 n+1)} \exp \left(\frac{-D_{e f f}(2 n+1)^{2} \pi^{2} t}{4 L^{2}}\right)
$$

The effective diffusivity coefficient can be determined from the slope of Equation (4) [17]:

$$
\ln (M R)=\ln \left(\frac{8}{\pi^{2}}\right)-\ln \left(\frac{-D_{e f f} \pi^{2} t}{4 L^{2}}\right)
$$

Generally, the diffusivity coefficient can be determined by plotting the experimental data of $\ln (M R)$ versus the time. The slope of the obtained line can be substituted in Equation (5) to determine the diffusivity coefficient [28]:

$$
K=\left(\frac{D_{e f f} \pi^{2}}{4 L^{2}}\right)
$$

\subsection{Specific Energy Consumption (SEC), Energy and Drying Efficiency}

After the drying tests, the drying curve and hence the drying time can be determined for each specific condition. The specific energy consumption of the drying process can be obtained by Equation (6) [32]:

$$
S E C=\left(\frac{E_{t}}{M_{w}}\right)
$$

Energy efficiency can be also determined by Equation (7) [33]:

$$
\eta_{e}=\left(\frac{E_{\text {evap }}}{E_{t}}\right) \times 100
$$

The HCIR dryer efficiency can be calculated by the following equation [34]:

$$
\eta_{d}=\left(\frac{E_{\text {evap }}+E_{\text {heating }}}{E_{t}}\right) \times 100
$$

\subsection{Shrinkage Measurement}

Shrinkage refers to the variations in the sample volume relative to its initial volume. This phenomenon can be assigned to the water removal from the cellular space and its substitution with the air. During the drying process, the shape and size of the product may also change. The alterations in the physical properties can finally result in some changes in the final texture (shrinkage) of the dried products. Shrinkage can be determined by [35]:

$$
S_{a}=\left(1-\frac{V_{t}}{V_{0}}\right) \times 100
$$

In which $S_{a}$ shows the shrinkage percentage, $V_{t}$ denotes the apparent volume of the dried sample $\left(\mathrm{cm}^{3}\right)$ after the time of $\mathrm{t}$ and $V_{0}$ represents the volume of the raw samples $\left(\mathrm{cm}^{3}\right)$. The apparent volume of the samples was measured by the toluene displacement method using a glass pycnometer $(50 \mathrm{~mL})$ in this method, the samples with determined 
weight were transferred into a semi-filled pycnometer containing toluene. The remaining volume of the pycnometer was then closely filled with the solvent and its weight was measured. The apparent volume of the samples $(V)$ can be determined by the following equations [36]:

$$
\begin{gathered}
V=V_{f}-\frac{M_{s f}}{\rho_{s}} \\
M_{s f}=M_{t+s}-M_{f}-M
\end{gathered}
$$

\subsection{Color Difference}

Color is a significant factor in the evaluation of food products and their marketability [37]. To evaluate the color of the samples, a color meter was used to measure various parameters including $L$ (lightness), $a$ (red-green), and $b$ (yellow-blue). The total color difference of the samples was also determined by Equation (12) [5].

$$
\Delta E=\sqrt{\left(L-L_{0}^{*}\right)^{2}+\left(a-a_{0}^{*}\right)^{2}+\left(b-b_{0}^{*}\right)^{2}}
$$

\subsection{Response Surface Methodology (RSM)}

In this research, the influence of the independent variables (drying air temperature in three levels of 50,60, and 70 and the sample thickness in three levels of 2, 4, and $6 \mathrm{~mm}$ ) on the dependent variables (drying time ( $\mathrm{min}$ ), effective moisture diffusivity $\left(\mathrm{m}^{2} / \mathrm{s}\right)$, SEC $(\mathrm{Mj} / \mathrm{kg})$, energy efficiency (\%), drying efficiency $(\%)$, shrinkage $(\%)$, and color difference) was evaluated for the samples pretreated by microwave, ultrasound, and blanching.

For the predicted responses, it was assumed that:

$$
y_{k}=f_{k}\left(\varepsilon_{1}, \varepsilon_{2}, \varepsilon_{3}\right)
$$

In which $y_{k}$ is the predicted response and $\varepsilon_{1}, \varepsilon_{2}$ and $\varepsilon_{3}$ denote the natural (independent) variables. The second-order response surface equations are also presented in Equation (14) [25]:

$$
y_{k}=\beta_{0}+\sum_{j=1}^{k} \beta_{j} x_{j}+\sum_{j=1}^{k} \beta_{j j} x_{j}^{2}+\sum \sum_{i<j}^{k} \beta_{i j} x_{i} x_{j}
$$

In the above equation, $\beta_{0}, \beta_{i}, \beta_{i j}$, and $\beta_{i j}$ are the regression coefficients. $x_{j}$ also denotes the coded input variables. Design-expert software was used for fitting the response surfaces and optimize the drying process through solving a multiple regression equation (Equation (14)) using historical data and RSM. The mathematical models of each response were assessed by multiple linear regression analysis. The statistical significance of the independent variables for the response variables was explored at the confidence level of $95 \%(p<0.05)$. Only the significant variables were included in the proposed regression equation. Finally, the optimal point of the process was determined according to the boundary conditions and the target functions as shown in Table 1.

Table 1. Boundary conditions and the independent and dependent variables.

\begin{tabular}{ccccc}
\hline Variables & Goal & Lower Limits & Upper Limits & Importance \\
\hline Drying air temperature $\left({ }^{\circ} \mathrm{C}\right)$ & In range & 50 & 70 & 5 \\
\hline Sample thickness $(\mathrm{mm})$ & In range & 2 & 6 & 5 \\
\hline Drying time $(\mathrm{min})$ & Minimum & 40 & 250 & 5 \\
\hline $\begin{array}{c}\text { Effective moisture } \\
\text { diffusivity }\left(\mathrm{m}^{2} / \mathrm{s}\right)\end{array}$ & Maximum & $1.01 \times 10^{-9}$ & $8.11 \times 10^{-9}$ & 5 \\
\hline$S E C(\mathrm{Mj} / \mathrm{kg})$ & Minimum & 21.57596 & 168.98 & 5 \\
\hline
\end{tabular}


Table 1. Cont.

\begin{tabular}{clccc}
\hline Variables & Goal & Lower Limits & Upper Limits & Importance \\
\hline Energy efficiency (\%) & Maximum & 0.89 & 15.23 & 5 \\
\hline Drying efficiency (\%) & Maximum & 2.11 & 21.2 & 5 \\
\hline Color difference & Minimum & 11.12 & 50.59 & 5 \\
\hline Shrinkage (\%) & Minimum & 19.28 & 67.84 & 5 \\
\hline
\end{tabular}

\subsection{Adaptive Neuro-Fuzzy Inference System (ANFIS)}

Compatible deductive neural-fuzzy systems combine the ANN and fuzzy logic concepts and employ a series of if-then fuzzy laws. In this study, neural-fuzzy modeling was achieved using Matlab software. To this end, a Sugeno system was employed and the desirable membership function was determined among various functions (triangular, trapezoidal, bell-shaped, Gaussian, Pi, type-II Gaussian, and sigmoid). Their membership degree was also obtained by trial and error. A combinational training algorithm (including error back propagations algorithm and minimum square error method) was employed to train and match with the fuzzy deductive system. This model was used to predict the drying time, effective moisture diffusivity coefficient, SEC, energy efficiency, drying efficiency, color, and shrinkage of the turnip samples dried under various pretreatment conditions. ANFIS inputs were the input air temperature and the sample thickness. In the present study, $75 \%$ of the data were used for training, and the remaining $25 \%$ were used for validation. The model evaluation and comparison was carried out by the determination coefficient $\left(R^{2}\right)$, and mean square root error (MSE).

$$
\begin{gathered}
R^{2}=1-\frac{\sum_{i=1}^{N}\left(S_{k}-T_{k}\right)^{2}}{\sum_{i=1}^{N}\left(S_{k}-T_{m}\right)^{2}} \\
M S E=\frac{1}{N} \sum_{i=1}^{N}\left(S_{K}-T_{k}\right)^{2}
\end{gathered}
$$

\section{Results and Discussion}

\subsection{Drying Time}

Table 2 shows the results obtained from the RSM method for predicting the drying time of the turnip slices based on the independent variables (drying air temperature, and slice thickness) for various pretreatments. The drying air temperature and slice thickness had a significant effect on the drying time for all three pretreatments $(p<0.05)$. The fitted models were linear and second-order polynomial equations. The positive and negative signs of the estimated regression in the equations indicated the significant direct and indirect effects on the response variable, respectively $(p<0.05)$.

Figure 1, depicts the effect of the drying temperature and slice thickness on the drying time of the turnip samples for the three studied pretreatments using an HCIR dryer. According to Figure $1 \mathrm{~b}$, the shortest drying time (40 $\mathrm{min})$ was for the drying air temperature of $70^{\circ} \mathrm{C}$ and thickness of $2 \mathrm{~mm}$ for the sample pretreated by microwave. The longest drying time $(250 \mathrm{~min})$ was also recorded for the drying air temperature of $50{ }^{\circ} \mathrm{C}$ for the control samples with the thickness of $6 \mathrm{~mm}$ (Figure 1a) the decline in the thickness and the rise in the temperature could enhance the thermal gradient within the turnip samples, hence raising the moisture evaporation rate. The microwave pretreatment also led to a high pressure difference between the center and the surface of the product and incremented the drying rate; this will enhance the mass transfer, hence shortening the drying time [38]. Similar results were reported by the other researchers using a convective dryer and various pretreatments for drying blackberry [39], apple [29], potatoes [31], and black mulberry [7]. 
According to Figure 1c,d), ultrasound pretreatment also caused a significant $(p<0.05)$ reduction in the drying time, as compared with the blanching pretreatment. The shortest drying time for the ultrasound $(140 \mathrm{~min})$ and blanching $(170 \mathrm{~min})$ pretreatments were observed in the sample with a thickness of $2 \mathrm{~mm}$ dried at the temperature of $70^{\circ} \mathrm{C}$. The ultrasound-induced cavitation can lead to the formation of a series of microchannels in the product which can decrease the boundary layer of the propagation and enhance the mass transfer; this will, in turn, facilitate the water removal from the product [37]. These results are in line with the previous reports. For apple [38] and rose flower [40] drying, the drying time was significantly decreased by ultrasound pretreatment as compared with the blanching pretreatment.

Table 2. Response surface method (RSM) modeling results for predicting the drying time under a hybrid convective-infrared (HCIR) dryer with various pretreatments.

\begin{tabular}{cccccc}
\hline Pretreatment & Equation & $\boldsymbol{R}^{\mathbf{2}}$ & Adj $\boldsymbol{R}^{\mathbf{2}}$ & Pred $\boldsymbol{R}^{\mathbf{2}}$ & $\boldsymbol{C V} \mathbf{( \% )}$ \\
\hline Control & $348.33-3.75 \times \mathrm{A}+13.75 \times \mathrm{B}$ & 0.9830 & 0.9773 & 0.9567 & 3.43 \\
Microwave & $87.77-0.833 \times \mathrm{A}+0.40 \times \mathrm{B}-$ & 0.9821 & 0.9713 & 0.9358 & 6.78 \\
Ultrasonic & $0.50 \times \mathrm{A} \times \mathrm{B}$ & & & \\
Blanching & $999.44-25.5 \times \mathrm{A}-12.91 \times \mathrm{B}+$ & 0.9944 & 0.9925 & 0.9862 & 1.97 \\
& $0.18 \times \mathrm{A}^{2}+2.70 \times \mathrm{B}^{2}$ & 0.9924 & 0.9847 & 0.9613 & 3.14
\end{tabular}

A: Drying temperature $\left({ }^{\circ} \mathrm{C}\right)$; B: Thickness $(\mathrm{mm}) \cdot R^{2}$ : determination coefficient and $C V$ : Coefficient of variation.

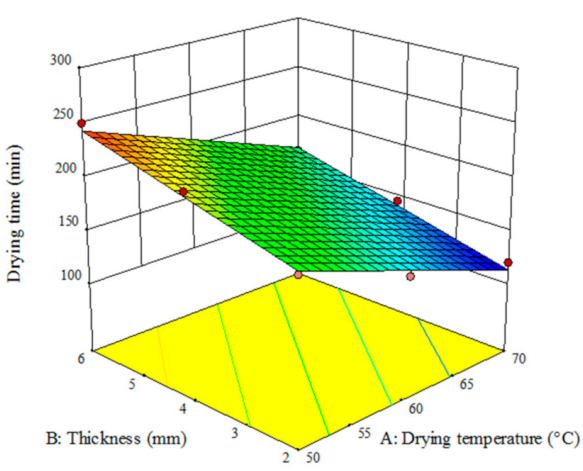

(a)

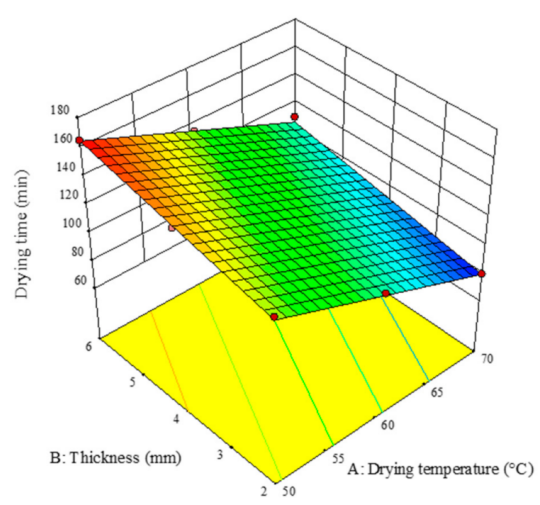

(c)

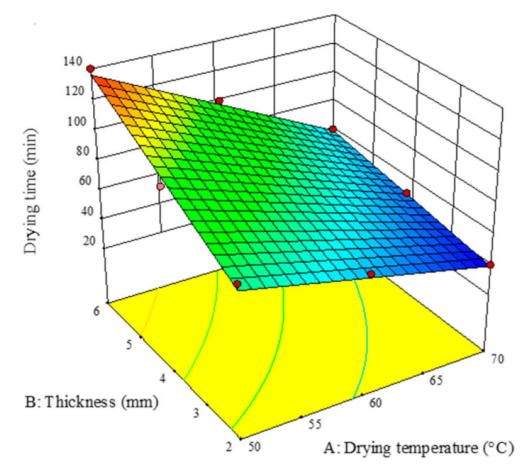

(b)

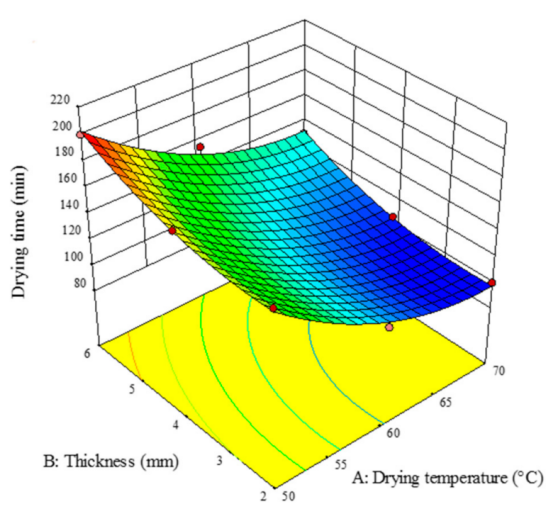

(d)

Figure 1. Effect of the drying temperature and sample thickness on the drying time (min) of the turnip slices dried under an hybrid convective-infrared (HCIR) dryer with various pretreatments (a) control, (b) microwave, (c) ultrasound, and (d) blanching. 


\subsection{Effective Moisture Diffusivity Coefficient ( $\left.D_{\text {eff }}\right)$}

Table 3 lists $D_{\text {eff }}$ results for various pretreatments at the studied temperature and thicknesses. $R^{2}$ was larger than 0.6 indicating that the demonstrated models were the best models for predicting the value of $D_{\text {eff. }}$ According to Table $3, D_{\text {eff }}$ showed a linear and significant variation in different pretreatments $(p<0.05)$.

Table 3. Response surface method (RSM) modeling for predicting effective moisture diffusivity coefficient $\left(D_{\text {eff }}\right)$ under a hybrid convective-infrared (HCIR) dryer with various pretreatments.

\begin{tabular}{|c|c|c|c|c|c|}
\hline Pretreatment & Equation & $R^{2}$ & $\operatorname{Adj} R^{2}$ & Pred $R^{2}$ & $C V(\%)$ \\
\hline Control & $\begin{aligned}-2.86 & \times 10^{-10}+3.85 \times 10^{-11} \times \mathrm{A} \\
& +1.26 \times 10^{-10} \times \mathrm{B}\end{aligned}$ & 0.9447 & 0.9263 & 0.8776 & 7.34 \\
\hline Microwave & $\begin{array}{c}-4.03 \times 10^{-9}+1.82 \times 10^{-10} \times \mathrm{A} \\
-6.14 \times 10^{-10} \times \mathrm{B}\end{array}$ & 0.9496 & 0.9328 & 0.8674 & 11.40 \\
\hline Ultrasonic & $\begin{array}{c}-7.51 \times 10^{-10}+6.38 \times 10^{-11} \times \\
\mathrm{A}-1.84 \times 10^{-10} \times \mathrm{B}\end{array}$ & 0.8594 & 0.8065 & 0.6041 & 12.99 \\
\hline Blanching & $\begin{array}{c}-7.34 \times 10^{-10}+5.16 \times 10^{-11} \times \\
\mathrm{A}-1.08 \times 10^{-10} \times \mathrm{B}\end{array}$ & 0.8996 & 0.8661 & 0.7817 & 9.71 \\
\hline
\end{tabular}

A: Drying temperature $\left({ }^{\circ} \mathrm{C}\right) ; \mathrm{B}$ : Thickness $(\mathrm{mm}) \cdot R^{2}$ : determination coefficient and $C V$ : Coefficient of variation.

Figure 2 shows the influence of the air temperature and turnip thickness on $D_{\text {eff }}$ for an HCIR dryer with various pretreatments. The highest $D_{\text {eff }}$ value $\left(8.11 \times 10^{-9} \mathrm{~m}^{2} / \mathrm{s}\right)$ was observed for the microwave-pretreated samples dried at the temperature of $70{ }^{\circ} \mathrm{C}$ and thickness of $2 \mathrm{~mm}$ (Figure $2 \mathrm{~b}$ ); while the lowest $D_{\text {eff }}\left(1.007 \times 10^{-9} \mathrm{~m}^{2} / \mathrm{s}\right)$ was recorded for the control samples with the thickness of $6 \mathrm{~mm}$ dried at $50{ }^{\circ} \mathrm{C}$ (Figure 2a). Other researchers reported the effective moisture diffusivity in the range of $5.47 \times 10^{-10}$ to $4.82 \times 10^{-9} \mathrm{~m}^{2} / \mathrm{s}[1,41]$. Based on Figure 3, an increase in the input air temperature and a decline in the sample's thickness can raise $D_{\text {eff. }}$. At high temperatures, the free water of the sample can be evaporated rapidly, hence dramatically reducing the drying time and increasing $D_{\text {eff. }}$. The use of microwave pretreatment is also enhanced, compared to the other pretreatments. By polarizing the water molecules, the microwave increased the internal temperature of the product. Moreover, it destroyed the product texture and formed channels with larger diameters, thus preventing the surface from hardening, hence accelerating the free water evaporation. $D_{\text {eff }}$ will decrease as a result of a decline in the drying time [33]. Similar results were reported by other researchers for cranberry snacks [17], blackberry [30], and okra [42]. They declared that the use of different pretreatments can increase the moisture diffusivity coefficient compared to the control samples.

Based on Figure 2c,d, $D_{\text {eff }}$ was higher in the ultrasonic pretreatment as compared with the blanching as ultrasonic treatment could open capillary paths due to the dispersion of the surface species; giving rise to longer microscopic channels as a result of the deformation of the cell. Therefore, ultrasonic pretreatment can deform and destroy the cell walls and accelerate moisture evaporation [38]. These results are in line with the previous reports by other researchers $[30,39]$. 


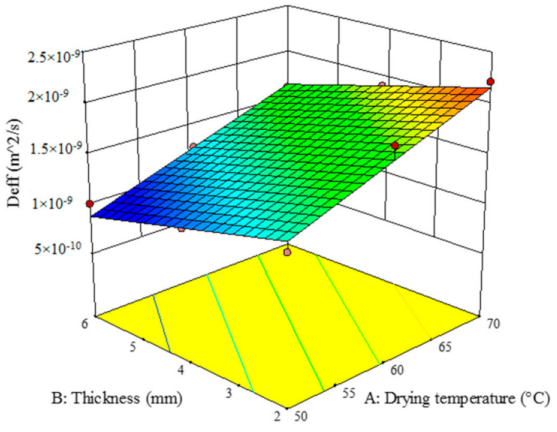

(a)

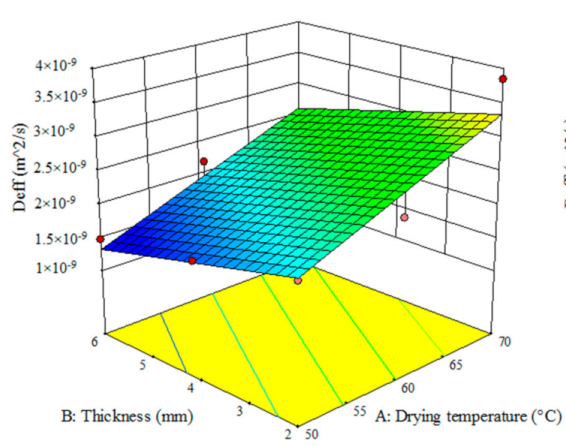

(c)

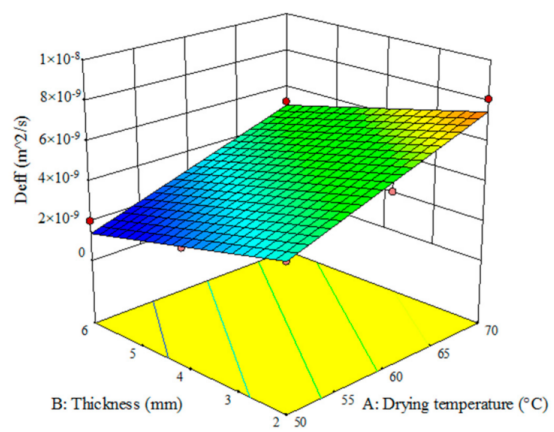

(b)

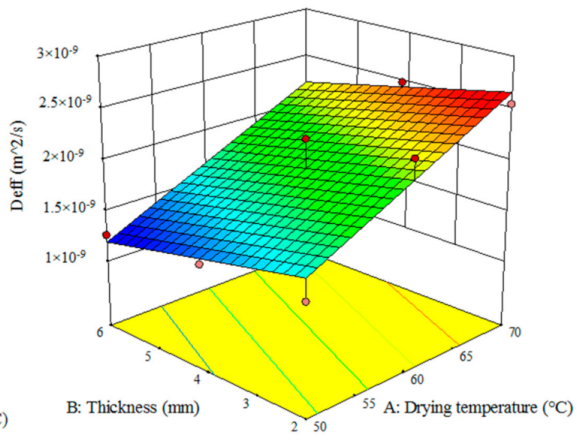

(d)

Figure 2. Effect of the drying temperature and sample thickness on the effective moisture diffusivity coefficient $\left(D_{\text {eff }}\right)\left(\mathrm{m}^{2} / \mathrm{s}\right)$ of the turnip slices dried under an HCIR dryer with various pretreatments (a) control, (b) microwave, (c) ultrasound, and (d) blanching.

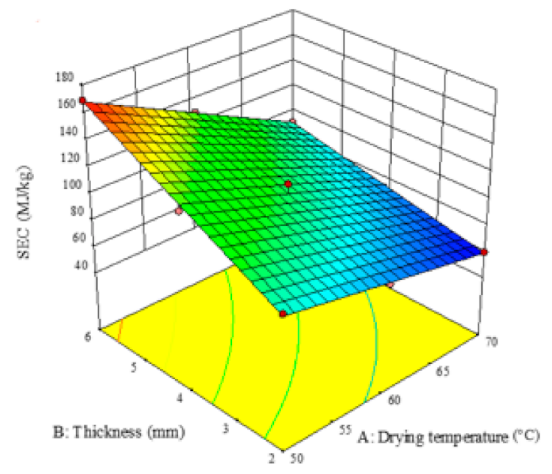

(a)

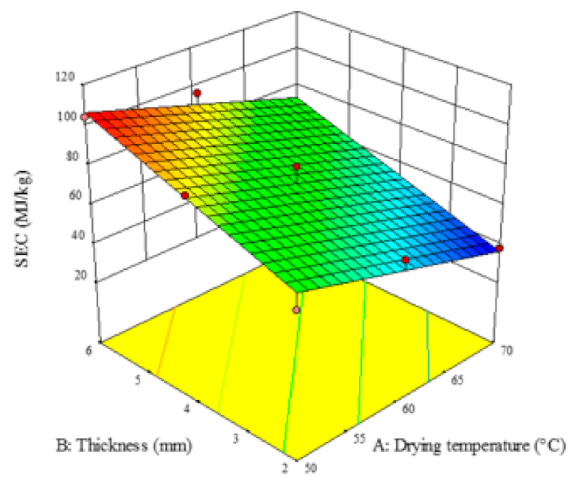

(c)

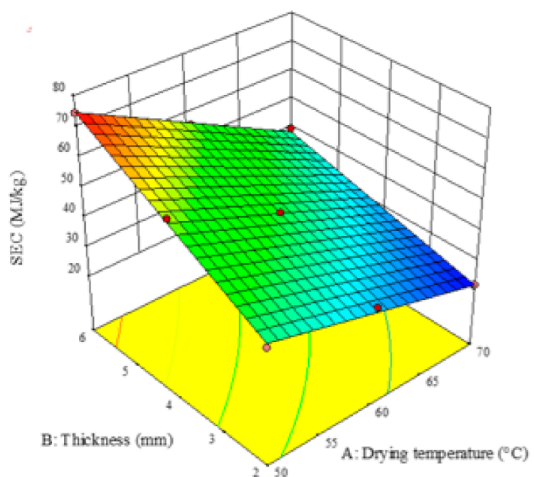

(b)

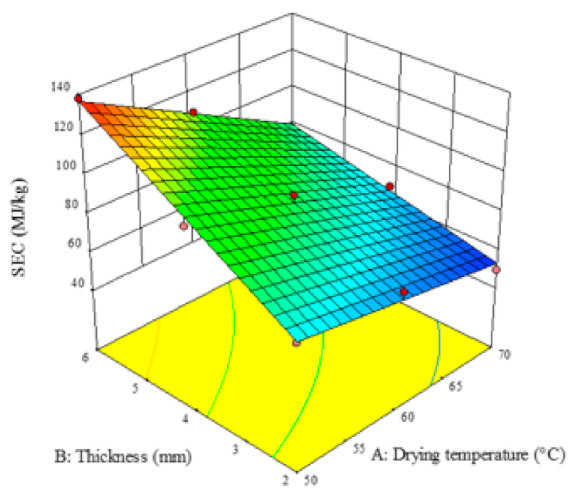

(d)

Figure 3. Effect of the drying temperature and sample thickness on the specific energy consumption (SEC, MJ/kg) of an HCIR dryer with various pretreatments (a) control, (b) microwave, (c) ultrasound, and (d) blanching. 


\subsection{Specific Energy Consumption (SEC)}

Table 4 shows the modeling results for SEC of drying turnip slices at various temperatures and sample thicknesses and pretreatments. Based on this table, the linear variables of air temperature and sample thickness could significantly $(p<0.05)$ affect SEC in different pretreatments. $R^{2}$ was larger than 0.84 , indicating the suitability of this linear model for predicting the value of SEC. It must be noted that only the coefficients with significant $(p<0.05)$ impact on SEC are included in the equation.

Table 4. Modeling results by the use of RSM for prediction of specific energy consumption (SEC) under an HCIR dryer with various pretreatments.

\begin{tabular}{|c|c|c|c|c|c|}
\hline Pretreatment & Equation & $R^{2}$ & $\operatorname{Adj} R^{2}$ & Pred $R^{2}$ & $C V(\%)$ \\
\hline Control & $\begin{array}{c}85.75-0.60 \times \mathrm{A}+45.78 \times \mathrm{B}- \\
0.53 \times \mathrm{A} \times \mathrm{B}\end{array}$ & 0.9909 & 0.9853 & 0.9830 & 4.05 \\
\hline Microwave & $\begin{array}{c}52.40-0.56 \times \mathrm{A}+18.83 \times \mathrm{B}- \\
0.20 \times \mathrm{A} \times \mathrm{B}\end{array}$ & 0.9954 & 0.9926 & 0.9777 & 3.25 \\
\hline Ultrasonic & $132.39-1.63 \times \mathrm{A}+9.32 \times \mathrm{B}$ & 0.9329 & 0.9106 & 0.8484 & 9.29 \\
\hline Blanching & $\begin{array}{c}44.38-0.06 \times \mathrm{A}+33.97 \times \mathrm{B}- \\
0.46 \times \mathrm{A} \times \mathrm{B}\end{array}$ & 0.9866 & 0.9786 & 0.9432 & 4.54 \\
\hline
\end{tabular}

A: Drying temperature $\left({ }^{\circ} \mathrm{C}\right) ; \mathrm{B}$ : Thickness $(\mathrm{mm})$.

Figure 3, depicts the effects of the temperature of the drying air and the sample thickness on the value of SEC for various pretreatments. The highest $S E C(168.98 \mathrm{MJ} / \mathrm{kg})$ was related to the control samples with the thickness of $6 \mathrm{~mm}$ dried at $50{ }^{\circ} \mathrm{C}$ (Figure 3a); while the lowest $S E C(21.57 \mathrm{~kJ} / \mathrm{kg})$ was observed for the microwave-pretreated samples with the thickness of $2 \mathrm{~mm}$ dried at $70{ }^{\circ} \mathrm{C}$ (Figure 3b). Similar results were reported by the other researchers in drying black mulberry [7], blackberry [39], and apple [34] using convective dryer under different pretreatments. They indicated that microwave-treated and control samples had the lowest and highest $S E C$ values, respectively. In the current study, microwave pretreatment declined the SEC compared to the other two pretreatments. Using microwave pretreatments, the destruction in the texture of the product will be enhanced which will elevate the moisture removal rate; hence declining the $S E C$ value [32]. Compared to blanching pretreatment, ultrasonic pretreatment led to lower $S E C$ values (Figure 3c,d). Food products such as turnip will form a hard layer on their surface following the moisture removal which may decelerate the evaporation. Ultrasonic pretreatment prevents the formation of this layer, hence increasing the moisture removal rate, shortening the drying time, and hence reducing the SEC value [20]. Similar results were reported for drying parsley leaves by a microwave-convective dryer [11] and blackberry by an HCIR dryer [43]; as they showed that ultrasound pretreatment can result in lower $S E C$ values, compared to the blanching pretreatment.

\subsection{Energy $\left(\eta_{e}\right)$ and Dryer $\left(\eta_{d}\right)$ Efficiency}

Table 5 lists the results obtained by modeling the effects of drying air temperature and sample thickness on the energy and dryer efficiency using an HCIR dryer with different pretreatments. Under all the studied conditions, $R^{2}$ was above 0.89 for the energy efficiency and above 0.8 for the dryer efficiency indicating that these models can predict the energy and dryer efficiencies well. Under the ultrasound pretreatment, the influence of the input air temperature and sample thickness was significant $(p<0.05)$ through a secondorder equation; while for the other pretreatment, these effects were linear and significant $(p<0.05)$. The variations in the dryer efficiency followed a second-order equation for the microwave and control samples; whereas the other pretreatments showed linear significant variation trends $(p<0.05)$. 
Table 5. RSM modeling of the energy and dryer efficiencies under an HCIR dryer with different pretreatments.

\begin{tabular}{|c|c|c|c|c|c|c|}
\hline Variable & Pretreatment & Equation & $R^{2}$ & Adj. $R^{2}$ & Pred. $R^{2}$ & $C V(\%)$ \\
\hline \multirow{4}{*}{$\eta_{e}$} & Control & $\begin{array}{c}-6.04+0.19 \times \mathrm{A}- \\
0.54 \times \mathrm{B}\end{array}$ & 0.9706 & 0.9608 & 0.9271 & 11.39 \\
\hline & Microwave & $\begin{array}{c}-7.97+0.37 \times \mathrm{A}+ \\
1.26 \mathrm{~B}-0.04 \times \mathrm{A} \times \\
\mathrm{B}\end{array}$ & 0.9951 & 0.9921 & 0.9721 & 2.73 \\
\hline & Ultrasonic & $\begin{array}{c}26.00-0.82 \times \mathrm{A}+ \\
0.73 \mathrm{~B}-0.02 \times \mathrm{A} \times \\
\mathrm{B}+0.008 \times \mathrm{A}^{2}\end{array}$ & 0.9893 & 0.9787 & 0.9276 & 3.58 \\
\hline & Blanching & $\begin{array}{c}-1.75+0.15 \times \mathrm{A}- \\
0.58 \times \mathrm{B}\end{array}$ & 0.9618 & 0.9491 & 0.8999 & 7.63 \\
\hline \multirow{4}{*}{$\eta_{d}$} & Control & $\begin{array}{c}11.70-0.44 \times \mathrm{A}- \\
0.11 \times \mathrm{B}+5.85 \times \\
\mathrm{A}^{2}-0.04 \times \mathrm{B}^{2}\end{array}$ & 0.9991 & 0.9981 & 0.9952 & 1.94 \\
\hline & Microwave & $\begin{array}{c}82.80-2.49 \times \mathrm{A}- \\
1.42 \times \mathrm{B}+0.02 \times \mathrm{B}^{2}\end{array}$ & 0.9897 & 0.9834 & 0.9665 & 3.69 \\
\hline & Ultrasonic & $\begin{array}{c}2.11+0.15 \times \mathrm{A}- \\
0.70 \times \mathrm{B}\end{array}$ & 0.9790 & 0.9720 & 0.9520 & 3.55 \\
\hline & Blanching & $\begin{array}{c}-3.57+0.21 \times \mathrm{A}- \\
0.54 \times \mathrm{B}\end{array}$ & 0.9314 & 0.9085 & 0.8067 & 9.24 \\
\hline
\end{tabular}

A: Drying temperature $\left({ }^{\circ} \mathrm{C}\right)$; B: Thickness $(\mathrm{mm})$. Energy $\left(\eta_{e}\right)$ and dryer $\left(\eta_{d}\right)$ efficiency.

A comparison of Figures 4 and 5 indicated that the elevation of the temperature enhanced the energy and dryer efficiencies. Temperature can augment the rate of moisture removal and hence decline the drying time; therefore, both the efficiencies will show ascending trends with temperature enhancement. With an increase in the sample thickness, the energy and dryer efficiencies declined as the drying time was increased. On the other hand, comparing the studied pretreatments showed that the highest efficiencies can be achieved using the microwave pretreatment (Figures $4 \mathrm{~b}$ and $5 \mathrm{~b}$ ); while the control samples exhibited the lowest efficiencies (Figures 4a and 5a). Microwave pretreatment destroyed the product texture and accelerated moisture removal. Results have shown that an increase in the drying temperature and a decline in the thickness of the sample can improve both energy and dryer efficiencies. As shown in Figure 4c,d, ultrasonic and blanching pretreatments enhanced the destruction in the product texture, hence no hard layer will be formed during the drying process, and therefore the product will be dried faster. Energy efficiency varied from $0.89 \%$ to $6.48 \%$ for the controls, $5.99 \%$ to $15.23 \%$ for the microwave pretreatment, $4.88 \%$ to $9.87 \%$ for the ultrasound pretreatment, and $1.90 \%$ to $7.77 \%$ for the blanching pretreatment. The dryer efficiency of the control, microwave, ultrasound, and blanching pretreatments, varied in $2.11-9.11 \%, 3.45-9.99 \%, 5.77-11.54 \%$, and $8.74-21.4 \%$, respectively. Other researchers have also shown that various pretreatments can enhance the energy and drying efficiencies [34]. 


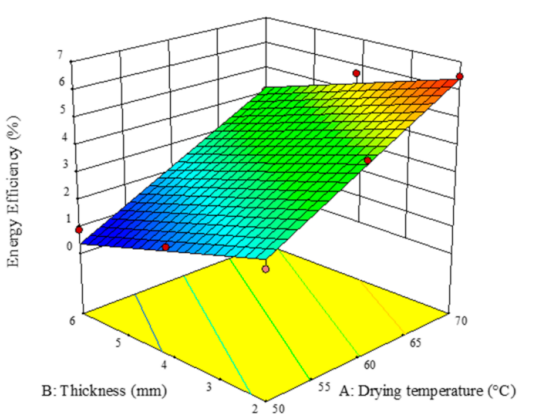

(a)

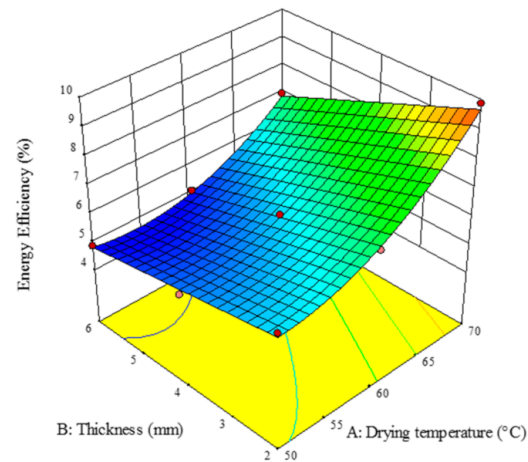

(c)

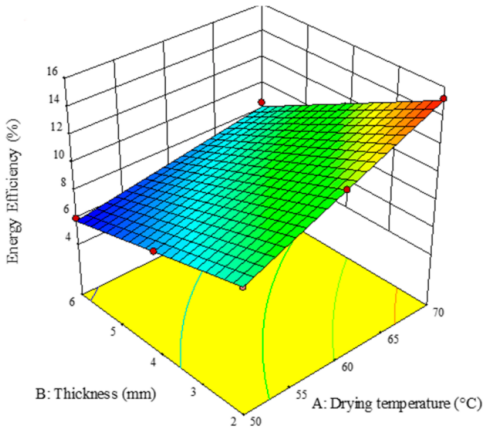

(b)

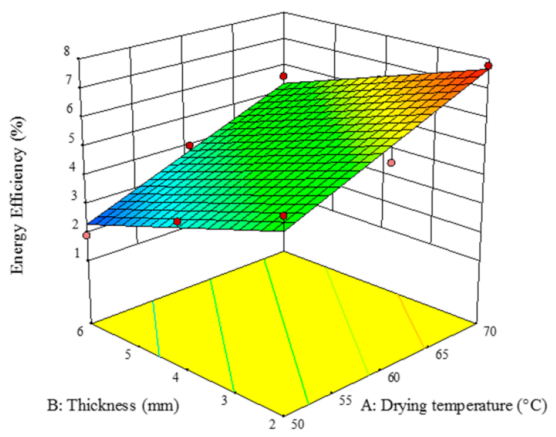

(d)

Figure 4. Effect of the drying temperature and sample thickness on the energy efficiency (\%) of an HCIR dryer with various pretreatments (a) control, (b) microwave, (c) ultrasound, and (d) blanching.

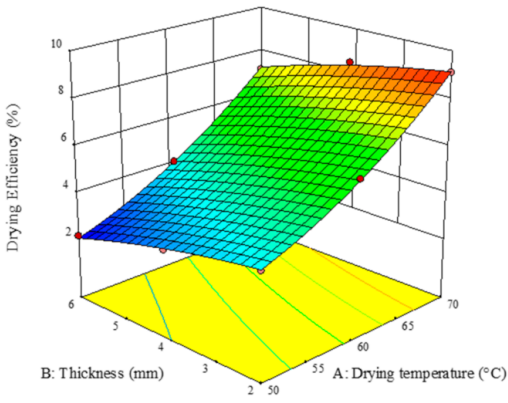

(a)

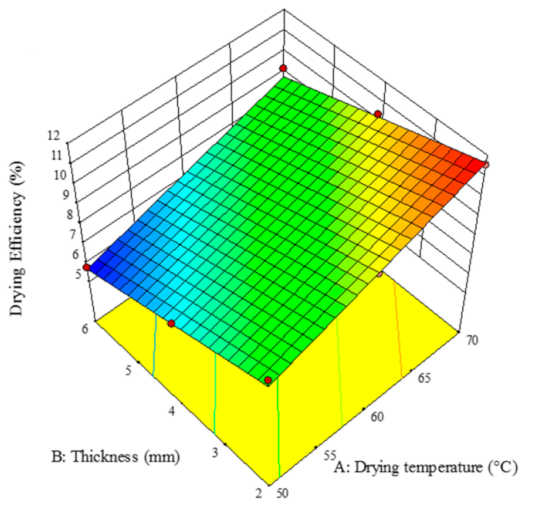

(c)

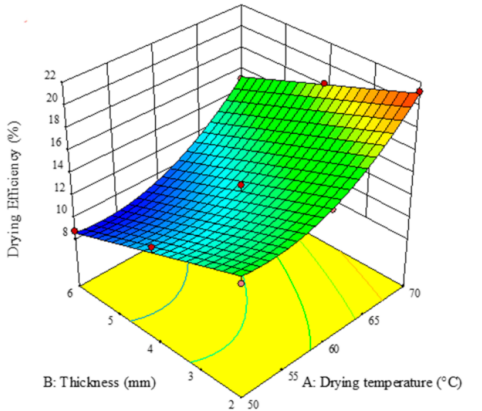

(b)

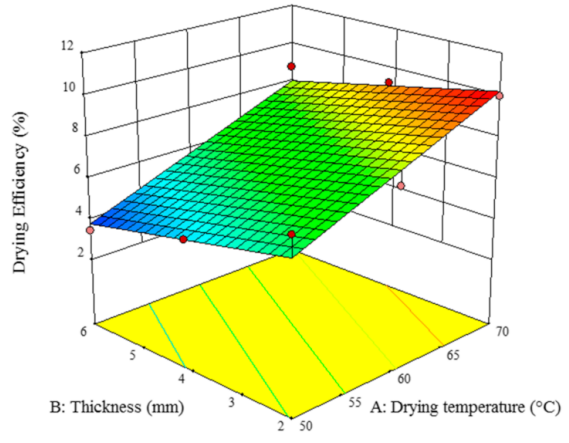

(d)

Figure 5. Effect of the drying temperature and sample thickness on the drying efficiency (\%) of an HCIR dryer with various pretreatments (a) control, (b) microwave, (c) ultrasound, and (d) blanching. 


\subsection{Shrinkage}

Table 6 lists the coefficients of the equations obtained by the fitted models for the shrinkage parameter. The air temperature and sample thickness could significantly affect the shrinkage of the samples $(p<0.05)$. Table 6 also shows $R^{2}$, adj- $R^{2}$, Pre- $R^{2}$, and $C V$ values. Regarding high $R^{2}$ values (above 0.97 ), the presented model is the best one for predicting the shrinkage level of the samples.

Table 6. RSM modeling for predicting shrinkage of the turnip samples under an HCIR dryer with different pretreatments.

\begin{tabular}{cccccc}
\hline Pretreatment & Equation & $\boldsymbol{R}^{\mathbf{2}}$ & Adj. $\boldsymbol{R}^{\mathbf{2}}$ & Pred. $\boldsymbol{R}^{\mathbf{2}} \boldsymbol{C V ( \% )}$ \\
\hline Control & $-14.24+0.90 \times \mathrm{A}+2.75 \times \mathrm{B}$ & 0.9821 & 0.9761 & 0.9547 & 2.80 \\
Microwave & $-12.17+0.59 \mathrm{~A}+2.63 \times \mathrm{B}$ & 0.9768 & 0.9691 & 0.9367 & 2.09 \\
Ultrasonic & $-3.99+0.36 \times \mathrm{A}+0.07 \times \mathrm{B}+$ & 0.9951 & 0.9922 & 0.9809 & 3.60 \\
Blanching & $-8.41+0.53 \times \mathrm{A}+3.76 \times \mathrm{B}$ & 0.9840 & 0.9787 & 0.9692 & 3.02 \\
\hline
\end{tabular}

A: Drying temperature $\left({ }^{\circ} \mathrm{C}\right)$; B: Thickness (mm).

Figure 6, shows the influence of the drying air temperature and sample thickness on the shrinkage of the samples pretreated by different methods. As seen, the highest shrinkage can be observed in the control samples while the ultrasound-pretreated samples exhibited the lowest shrinkage (Figure 6a). A comparison of the pretreatments indicated that blanching led to the highest shrinkage as the intercellular water was replaced by air which led to stress in the cell structure, hence the texture failed in maintaining its structure (Figure 6d). As a result, the extracellular structure will collapse resulting in higher shrinkage [29].

The shrinkage increased by increasing the temperature and sample thickness. An increment in the drying temperature enhanced the thermal gradient between the product and the environment, promoting the moisture migration from the internal layers to the sliced layers; this will cause a moisture gradient between the surface and internal layers and hence augment the shrinkage [18]. By drying mushrooms [44] and barley seeds [35] at various temperatures, other researchers also showed an increase in the shrinkage by the temperature elevation. The reason for the increased shrinkage in thicker samples can be explained as follows: a rise in the sample thickness will reduce the water release of the cell and hence decline the stress applied to the cell by the liquid. Such a decline in the stress will enhance the textural shrinkage. The shrinkage of the turnip samples pretreated by microwave (Figure 6b), ultrasound (Figure 6c), and blanching (Figure 6d) method, as well as the controls, varied from $24.28-46.67 \%, 19.28-42.49 \%, 26.20-52.21 \%$, and $36.36-67.84 \%$, respectively. 


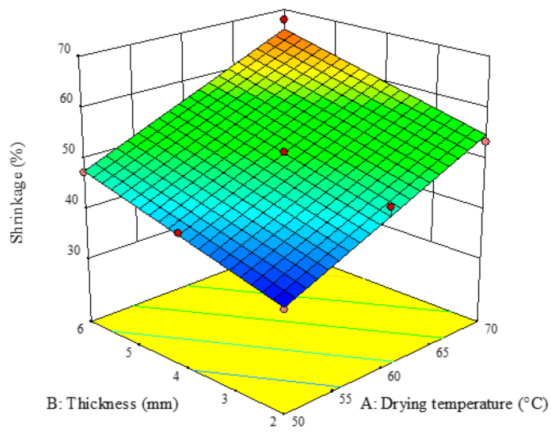

(a)

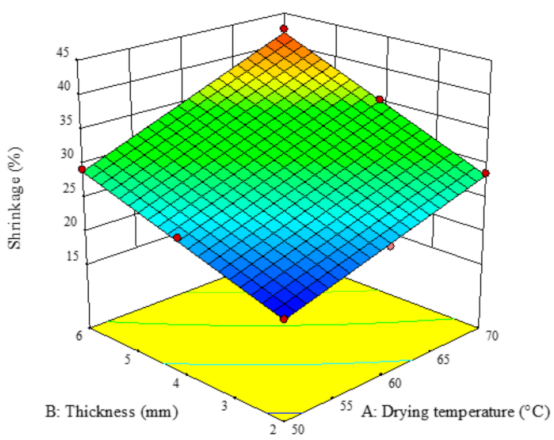

(c)

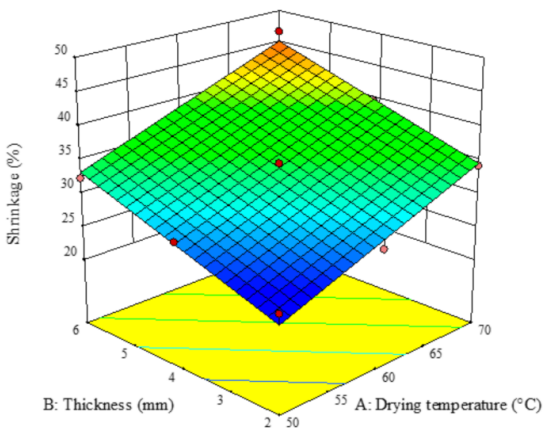

(b)

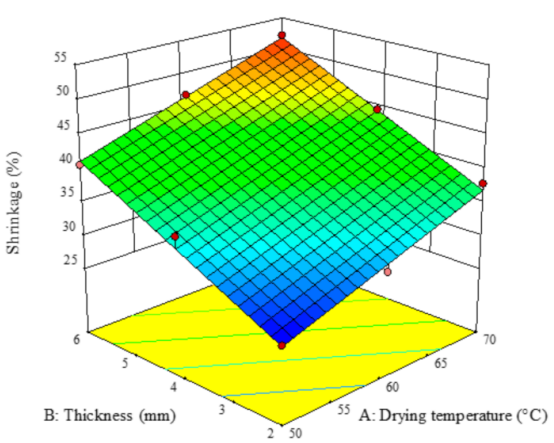

(d)

Figure 6. Effect of the drying temperature and sample thickness on the shrinkage (\%) of the turnip slices dried under an HCIR dryer with various pretreatments (a) control, (b) microwave, (c) ultrasound, and (d) blanching.

\subsection{Color Difference $(\Delta E)$}

As presented in Table 7 , the drying air temperature and sample thickness linearly and significantly altered $\Delta E$ of the dried turnip $(p<0.059) . R^{2}$, adj- $R^{2}$, and Pre- $R^{2}$ values of $\Delta E$ index were above 0.97 , above 0.96 , and above 0.92 . Therefore, the presented equations can well fit the experimental data.

Table 7. RSM modeling for predicting color difference $(\Delta E)$ of the samples dried under an HCIR dryer with different pretreatments.

\begin{tabular}{|c|c|c|c|c|c|}
\hline Pretreatment & Equation & $R^{2}$ & Adj. $R^{2}$ & Pred. $R^{2}$ & $C V(\%)$ \\
\hline Control & $+7.31+0.41 \times \mathrm{A}+2.3 \times 6 \mathrm{~B}$ & 0.9861 & 0.9815 & 0.9706 & 1.79 \\
\hline Microwave & $\begin{aligned}-33.93+0.79 & \times \mathrm{A}+9.08 \times \mathrm{B}- \\
0.08 & \times \mathrm{A} \times \mathrm{B}\end{aligned}$ & 0.9880 & 0.9808 & 0.9580 & 3.72 \\
\hline Ultrasonic & $-21.38+0.51 \times \mathrm{A}+3.09 \times \mathrm{B}$ & 0.9871 & 0.9829 & 0.9686 & 4.21 \\
\hline Blanching & $-10.61+0.49 \times \mathrm{A}+3.15 \times \mathrm{B}$ & 0.9720 & 0.9627 & 0.9269 & 4.31 \\
\hline
\end{tabular}

A: Drying temperature $\left({ }^{\circ} \mathrm{C}\right) ; \mathrm{B}$ : Thickness $(\mathrm{mm})$.

Figure 7 shows the effects of the drying temperature and sample thickness on $\Delta E$ of the turnip samples dried by an HCIR dryer for different pretreatments. An increase in the temperature and sample thickness enhanced the $\Delta E$ value since an increase in these two factors implies drying at higher temperatures which will result in browning reactions and an increase of the brunt areas on the sample surface [11]. Similar results were reported on the variations of $\Delta E$ during drying different products such as almond kernel [45] and cabbage [18]. 


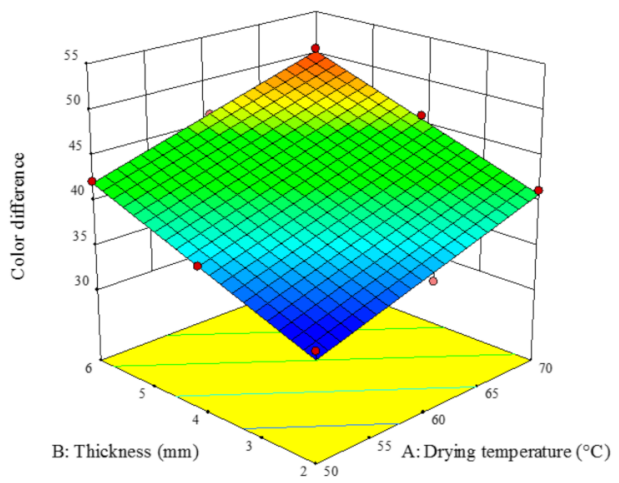

(a)

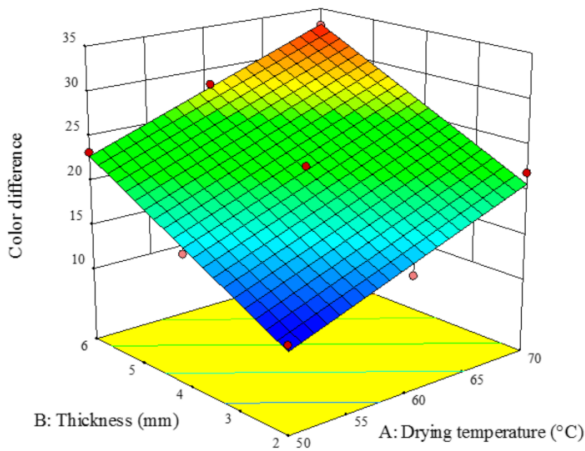

(c)

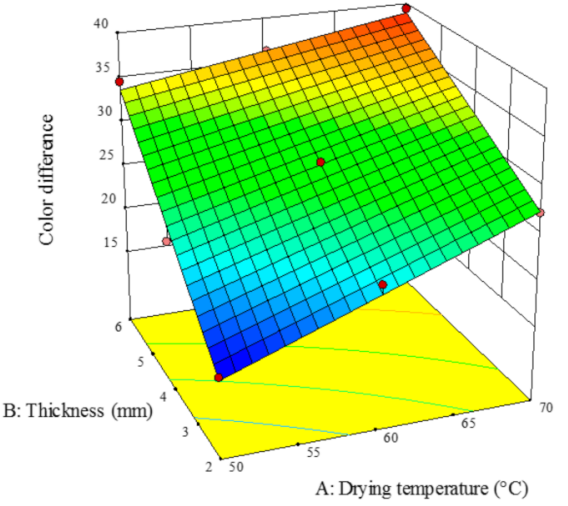

(b)

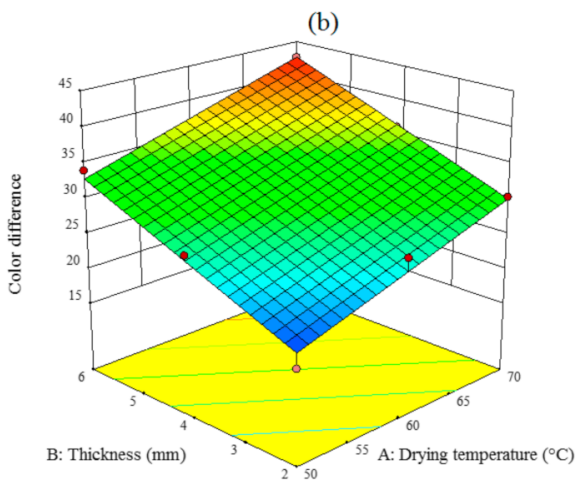

(d)

Figure 7. Effect of the drying temperature and sample thickness on the color difference of the turnip slices dried under an HCIR dryer with various pretreatments (a) control, (b) microwave, (c) ultrasound, and (d) blanching.

The highest color variation $(\Delta E)$ was 50.59 and observed in the control samples with the thickness of $6 \mathrm{~mm}$ dried at $70{ }^{\circ} \mathrm{C}$ (Figure 7a); while the lowest color difference (11.12) was for the ultrasound-treated samples with the thickness of $2 \mathrm{~mm}$ dried at $50{ }^{\circ} \mathrm{C}$ (Figure 7c). The results indicated that the color indices were closer to the fresh samples when the products were thinner and dried at lower temperatures. According to Figure 7, the studied pretreatments caused some color variations. Similar results were also reported for other agricultural products such as mushrooms [44], star anise [46], cranberry snacks [17], and blackberry [39].

\subsection{Optimization}

Table 8 lists the optimized values of the independent and response variables along with their desirability function based on the desirability index. The optimal independent variables were drying temperature of $70^{\circ} \mathrm{C}$ and thickness of $2 \mathrm{~mm}$ for all the pretreatments and control samples (accuracy over 0.89 ). Under this optimal condition, the response variables such as drying time (11.33 $\mathrm{min}), \operatorname{SEC}(59.31 \mathrm{MJ} / \mathrm{kg})$, shrinkage $(54.87 \%)$ and color variation (40.83) were minimized while, $D_{\text {eff }}\left(2.15 \times 10^{-9} \mathrm{~m}^{2} / \mathrm{s}\right)$ energy efficiency $(6.64 \%)$ and dryer efficiency (9.13) showed their maximal levels. Other researchers also used the RSM method to optimize the drying process of various crops including apricots [45], lavender leaves [25], sunflower seeds [21], and pistachio [47]. 
Table 8. Optimization of the response parameters for turnip drying under an HCIR dryer with different pretreatments by RSM.

\begin{tabular}{|c|c|c|c|c|c|c|c|c|c|c|}
\hline Pretreatment & $\begin{array}{c}\text { Air } \\
\text { Temperature } \\
\left({ }^{\circ} \mathrm{C}\right)\end{array}$ & $\begin{array}{l}\text { Thickness } \\
\text { (mm) }\end{array}$ & $\begin{array}{l}\text { Time } \\
\text { (min) }\end{array}$ & $D_{e f f}\left(\mathrm{~m}^{2} / \mathrm{s}\right)$ & $\begin{array}{c}S E C \\
(\mathrm{MJ} / \mathrm{kg})\end{array}$ & $\begin{array}{c}\eta_{e} \\
(\%)\end{array}$ & $\begin{array}{c}\eta_{d} \\
(\%)\end{array}$ & $\begin{array}{c}\text { Shrinkage } \\
(\%)\end{array}$ & $\begin{array}{c}\text { Color } \\
\text { Difference }\end{array}$ & Desirability \\
\hline Control & 70 & 2 & 113.33 & $2.15 \times 10^{-9}$ & 59.31 & 6.40 & 9.13 & 54.87 & 40.83 & 0.896 \\
\hline Microwave & 70 & 2 & 39.44 & $7.49 \times 10^{-9}$ & 21.59 & 15.12 & 21.06 & 34.62 & 27.40 & 0.893 \\
\hline Ultrasonic & 70 & 2 & 79.72 & $3.34 \times 10^{-9}$ & 36.59 & 9.67 & 11.64 & 28.43 & 20.75 & 0.892 \\
\hline Blanching & 70 & 2 & 97.77 & $2.66 \times 10^{-9}$ & 53.30 & 7.66 & 10.20 & 36.87 & 30.07 & 0.911 \\
\hline
\end{tabular}

\subsection{ANIFIS}

Table 9 presents the results obtained by the ANFIS model to predict the drying time, $D_{\text {eff, }}, S E C$, energy and dryer efficiencies, shrinkage, and color variation of the dried turnip samples using an HCIR dryer. To measure the performance of the model, developed equations and two statistical functions, root mean square error (RMSE) and determination coefficient $\left(R^{2}\right)$, were used. In this table the lowest RMSE and highest $R^{2}$ are presented. According to Table $7, R^{2}$ of prediction of drying time, $D_{\text {eff, }}, S E C$, energy efficiency, dryer efficiency, shrinkage, and color were $0.9965,0.989,0.000,0.9993,0.9989$, and 0.9990, respectively (other pretreatments are shown in Table 9). According to Table 9, it can be concluded that the ANFIS model offered higher accuracy for all the studied parameters as compared with the RSM model. By drying almonds [20] and blackberry [30], the researchers have shown that the ANFIS model can successfully predict the drying properties of the products.

Table 9. Prediction of the response parameters for turnip drying under an HCIR dryer with different pretreatments by ANFIS.

\begin{tabular}{|c|c|c|c|c|c|c|c|c|c|c|c|c|c|c|}
\hline \multirow{2}{*}{ Pretreatment } & \multicolumn{2}{|c|}{$\begin{array}{l}\text { Time } \\
(\mathrm{min})\end{array}$} & \multicolumn{2}{|c|}{$\begin{array}{c}\text { Deff } \\
\left(\mathrm{m}^{2} / \mathrm{s}\right)\end{array}$} & \multicolumn{2}{|c|}{$\begin{array}{c}S E C \\
(\mathrm{Mj} / \mathrm{kg})\end{array}$} & \multicolumn{2}{|c|}{$\begin{array}{c}\eta_{e} \\
(\%)\end{array}$} & \multicolumn{2}{|c|}{$\begin{array}{c}\eta_{d} \\
(\%)\end{array}$} & \multicolumn{2}{|c|}{$\begin{array}{c}\text { Shrinkage } \\
(\%)\end{array}$} & \multicolumn{2}{|c|}{ Color } \\
\hline & $R^{2}$ & MSE & $R^{2}$ & MSE & $R^{2}$ & MSE & $R^{2}$ & MSE & $R^{2}$ & MSE & $R^{2}$ & MSE & $R^{2}$ & MSE \\
\hline Control & 0.9975 & 0.0012 & 0.9690 & 0.0059 & 0.9995 & 0.0002 & 0.9859 & 0.0012 & 0.9994 & 0.0002 & 0.9968 & 0.0009 & 0.9979 & 0.0008 \\
\hline Microwave & 0.9965 & 0.0019 & 0.9890 & 0.0022 & 0.9990 & 0.0004 & 0.9993 & 0.0004 & 0.9989 & 0.0004 & 0.9869 & 0.0020 & 0.9990 & 0.0004 \\
\hline Ultrasonic & 0.9990 & 0.0004 & 0.9797 & 0.0048 & 0.9805 & 0.0017 & 0.9896 & 0.00011 & 0.9939 & 0.0010 & 0.9996 & 0.0002 & 0.9990 & 0.0004 \\
\hline Blanching & 0.9980 & 0.0008 & 0.9708 & 0.0054 & 0.9989 & 0.0004 & 0.9979 & 0.0008 & 0.9928 & 0.0011 & 0.9979 & 0.0008 & 0.9988 & 0.0004 \\
\hline
\end{tabular}

\section{Conclusions}

In this study, drying time, $D_{\text {eff }}, S E C$, energy efficiency, drying efficiency, color, and shrinkage of the turnip samples dried by an HCIR dryer were evaluated under various pretreatments (microwave, ultrasonic, and blanching). The following results were obtained:

I. The lowest drying time $(40 \mathrm{~min}), D_{\text {eff }}\left(1.007 \times 10^{-9} \mathrm{~m}^{2} / \mathrm{s}\right)$, and $\operatorname{SEC}(21.57 \mathrm{Mj} / \mathrm{kg})$ were observed in the microwave pretreatment.

II. Energy and dryer efficiencies of $0.89-15.23 \%$ and $2.11-21.20 \%$ were recorded for the microwave-pretreated samples with a thickness of $2 \mathrm{~mm}$ which were dried at $70{ }^{\circ} \mathrm{C}$.

III. In the HCIR dryer, SEC declined by increasing the temperature and reducing the thickness, microwave power, and blanching temperature; the energy and dryer efficiencies were increased.

IV. The ultrasonic pretreatment led to the lowest shrinkage $(19.28 \%)$ and color variation (11.12) moreover, an increase in the temperature and sample thickness enhanced the shrinkage and color variations for all the pretreatments.

V. The optimal condition for the lowest SEC and the highest energy and dryer efficiencies involved the air temperature of $70^{\circ} \mathrm{C}$ and sample thickness of $2 \mathrm{~mm}$ which led to the desirability of over $89 \%$ for all the pretreatments.

VI. A comparison of the parameter prediction by RSM and ANFIS models indicated that the RSM model exhibited very good performance in modeling and optimizing 
the process; while the ANFIS method did not have this capability. ANFIS, however, showed better performance in predicting the dependent variables.

This study provides an in-depth understanding of the drying kinetics, and energy consumption, energy efficiency and quality properties (shrinkage and color) of HCIR drying process with four pretreatments, which will be helpful for the selection of pretreatment methods in the turnip industry.

Author Contributions: Conceptualization, E.T. and M.K.; methodology, E.T. and M.K.; validation, E.T. and M.K.; formal analysis, E.T.; investigation, E.T. and M.K.; resources, E.T. and A.S.; data curation, E.T. and M.K.; writing-original draft preparation, E.T. and A.S.; writing-review and editing, E.T., A.S.; and M.K.; visualization, E.T. and A.S.; funding acquisition, E.T. and A.S. All authors have read and agreed to the published version of the manuscript.

Funding: This research was funded by the office of vice chancellor for research at Mohaghegh Ardabili University (by a research project with Number: 99.d.9.8954 and date 2020.08.15), and Wrocław University of Environmental and Life Sciences.

Institutional Review Board Statement: Not applicable.

Informed Consent Statement: Not applicable.

Data Availability Statement: Data for this research will available.

Acknowledgments: The authors are highly thankful to Department of Agricultural Technology Engineering, Mohaghegh Ardabili University, Ardabil, Iran for providing facilities to conduct this research work.

Conflicts of Interest: The authors declare no conflict of interest.

\section{Abbreviations}

$D_{\text {eff }} \quad$ Effective moisture diffusion coefficient $\left(\mathrm{m}^{2} / \mathrm{s}\right)$

$E_{t} \quad$ Total energy input to dryer (MJ)

EU Total energy consumption

Evap Energy consumed to evaporate moisture from drying samples (kJ)

Eneating Energy for the material heating $(\mathrm{kJ})$

$M \quad$ weight of the sample $(\mathrm{g})$

Mf weight of pycnometer $(\mathrm{g})$,

$M_{b} \quad$ Initial moisture content $\left(\mathrm{kg}_{\text {water }} / \mathrm{kg}\right.$ dry matter $)$

$M_{e} \quad$ Equilibrium moisture content $(\mathrm{kg}$ water $/ \mathrm{kg}$ dry matter $)$

$M_{t} \quad$ Moisture content at any time $\left(\mathrm{kg}_{\text {water }} / \mathrm{kg}\right.$ dry matter $)$

MR Moisture ratio

Msf weight of the toluene for filling the pycnometer (g)

$M t+s \quad$ weight of pycnometer plus the weights of the sample and toluene $(\mathrm{g})$

$N \quad$ Number of data values

$R^{2} \quad$ determination coefficient

$S_{b} \quad$ Shrinkage (\%)

SEC Specific energy consumption $(\mathrm{MJ} / \mathrm{kg})$

$S_{k} \quad$ Predict data

$t \quad$ Drying time (min)

$T_{k} \quad$ Experimental data

$T_{m} \quad$ average predicted values

Vf pycnometer volume $\left(\mathrm{cm}^{3}\right)$

$V_{o} \quad$ Final volume $\left(\mathrm{cm}^{3}\right)$

$V_{t} \quad$ Initial volume $\left(\mathrm{cm}^{3}\right)$

$\Delta E \quad$ Total color change

$\Delta L^{*}, \Delta b^{*}, \Delta a^{*} \quad$ Differences between the color of the fresh and dried sample

ps density of toluene $\left(0.87 \mathrm{~g} / \mathrm{cm}^{3}\right.$ at $\left.20^{\circ} \mathrm{C}\right)$ 


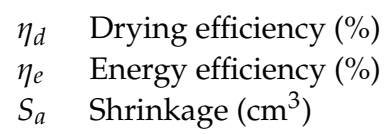

\section{References}

1. Kaveh, M.; Chayjan, R.A. Modeling thin-layer drying of turnip slices under semi-industrial continuous band dryer. J. Food Process. Preserv. 2016, 41, e12778. [CrossRef]

2. Xue, Y.; Chen, J.-N.; Han, H.-T.; Liu, C.-Q.; Gao, Q.; Li, J.-H.; Li, D.-J.; Tanokura, M. Multivariate analyses of the physicochemical properties of turnip (Brassica rapa L.) chips dried using different methods. Dry. Technol. 2019, 38, 411-419. [CrossRef]

3. Sun, Q.; Zhang, M.; Mujumdar, A.S. Recent developments of artificial intelligence in drying of fresh food: A review. Crit. Rev. Food Sci. Nutr. 2019, 59, 2258-2275. [CrossRef] [PubMed]

4. Jin, W.; Mujumdar, A.S.; Zhang, M.; Shi, W. Novel drying techniques for spices and herbs: A review. Food Eng. Rev. 2017, 10, 34-45. [CrossRef]

5. Rawson, A.; Tiwari, B.; Tuohy, M.; O’Donnell, C.; Brunton, N. Effect of ultrasound and blanching pretreatments on polyacetylene and carotenoid content of hot air and freeze dried carrot discs. Ultrason. Sonochem. 2011, 18, 1172-1179. [CrossRef] [PubMed]

6. Kaveh, M.; Taghinezhad, E.; Aziz, M. Effects of physical and chemical pretreatments on drying and quality properties of blackberry (Rubus spp.) in hot air dryer. Food Sci. Nutr. 2020, 8, 3843-3856. [CrossRef]

7. Adabi, E.M.; Motevali, A.; Nikbakht, A.M.; Khoshtaghaza, H.M. Investigation of some pretreatments on energy and specific energy consumption drying of black mulberry. Chem. Ind. Chem. Eng. Q. 2013, 19, 89-105. [CrossRef]

8. Taghinezhad, E.; Kaveh, M.; Rasooli Sharabiani, V. Blackberry drying with various pretreatments of thermal, pulsed, chemical and mechanical using convective-infrared combined method. Innov. Food Technol. 2020, 7, 277-298. [CrossRef]

9. Wang, H.; Liu, Z.-L.; Vidyarthi, S.K.; Wang, Q.-H.; Gao, L.; Li, B.-R.; Wei, Q.; Liu, Y.-H.; Xiao, H.-W. Effects of different drying methods on drying kinetics, physicochemical properties, microstructure, and energy consumption of potato (Solanum tuberosum L.) cubes. Dry. Technol. 2020, 1-14. [CrossRef]

10. Sahin, M.; Doymaz, I. Estimation of cauliflower mass transfer parameters during convective drying. Heat Mass Transf. 2016, 53, 507-517. [CrossRef]

11. Sledz, M.; Wiktor, A.; Rybak, K.; Nowacka, M.; Witrowa-Rajchert, D. The impact of ultrasound and steam blanching pre-treatments on the drying kinetics, energy consumption and selected properties of parsley leaves. Appl. Acoust. 2016, 103, 148-156. [CrossRef]

12. Amami, E.; Khezami, W.; Mezrigui, S.; Badwaik, L.S.; Bejar, A.K.; Perez, C.T.; Kechaou, N. Effect of ultrasound-assisted osmotic dehydration pretreatment on the convective drying of strawberry. Ultrason. Sonochem. 2017, 36, 286-300. [CrossRef] [PubMed]

13. Rojas, M.L.; Augusto, P.E. Ethanol and ultrasound pre-treatments to improve infrared drying of potato slices. Innov. Food Sci. Emerg. Technol. 2018, 49, 65-75. [CrossRef]

14. Esmaeili, A.M.; Nikbakht, A.; Motevali, A.; Mousavi, S.S. Investigation of black mulberry drying kinetics applying different pretreatments. J. Agr. Sci. Tech. 2013, 15, 23-34.

15. Mierzwa, D.; Szadzińska, J.; Pawłowski, A.; Pashminehazar, R.; Kharaghani, A. Nonstationary convective drying of raspberries, assisted by microwaves and ultrasound. Dry. Technol. 2019, 37, 988-1001. [CrossRef]

16. Dehghannya, J.; Gorbani, R.; Ghanbarzadeh, B. Effect of ultrasound-assisted osmotic dehydration pretreatment on drying kinetics and effective moisture diffusivity of Mirabelle plum. J. Food Process. Preserv. 2015, 39, 2710-2717. [CrossRef]

17. Nowacka, M.; Wiktor, A.; Anuszewska, A.; Dadan, M.; Rybak, K.; Witrowa-Rajchert, D. The application of unconventional technologies as pulsed electric field, ultrasound and microwave-vacuum drying in the production of dried cranberry snacks. Ultrason. Sonochem. 2019, 56, 1-13. [CrossRef]

18. Show, P.L.; Han, M.; Gao, X.; Han, Y.; Show, P.-L.; Liu, C.; Ye, X.; Xie, G. Applications of water blanching, surface contacting ultrasound-assisted air drying, and their combination for dehydration of white cabbage: Drying mechanism, bioactive profile, color and rehydration property. Ultrason. Sonochem. 2019, 53, 192-201. [CrossRef]

19. Abbasi, S.A.; Sharifzadeh, F.; Tavakol, A.R.; Majnoun, H.N.; Gazor, H. Optimization of processing parameters of soybean seeds dried in a constant-bed dryer using response surface methodology. J. Agric. Sci. Technol. 2010, 12, 409-423.

20. Kaveh, M.; Jahanbakhshi, A.; Abbaspour-Gilandeh, Y.; Taghinezhad, E.; Moghimi, M.B.F. The effect of ultrasound pre-treatment on quality, drying, and thermodynamic attributes of almond kernel under convective dryer using ANNs and ANFIS network. J. Food Process Eng. 2018, 41, e12868. [CrossRef]

21. Dibagar, N.; Kowalski, S.J.; Chayjan, R.A.; Figiel, A. Accelerated convective drying of sunflower seeds by high-power ultrasound: Experimental assessment and optimization approach. Food Bioprod. Process. 2020, 123, 42-59. [CrossRef]

22. Wang, G.; Deng, Y.; Xu, X.; He, X.; Zhao, Y.; Zou, Y.; Liu, Z.; Yue, J. Optimization of air jet impingement drying of okara using response surface methodology. Food Control 2016, 59, 743-749. [CrossRef]

23. Noshad, M.; Mohebbi, M.; Shahidi, F.; Mortazavi, S.A. Multi-objective optimization of osmotic-ultrasonic pretreatments and hot-air drying of quince using response surface methodology. Food Bioprocess Technol. 2011, 5, 2098-2110. [CrossRef]

24. Shi, Q.; Zheng, Y.; Zhao, Y. Optimization of combined heat pump and microwave drying of yacon (Smallanthus sonchifolius) using response surface methodology. J. Food Process. Preserv. 2014, 38, 2090-2098. [CrossRef]

25. Homayounfar, H.; Amiri Chayjan, R.; Sarikhani, H.; Kalvandi, R. Optimization of different drying systems for lavender leaves applying response surface methodology. J. Agric. Sci. Technol. 2020, 22, 679-692. 
26. Dibagar, N.; Chayjan, R.A.; Kowalski, S.J.; Peyman, S.H. Deep bed rough rice air-drying assisted with airborne ultrasound set at $21 \mathrm{kHz}$ frequency: A physicochemical investigation and optimization. Ultrason. Sonochem. 2019, 53, 25-43. [CrossRef]

27. Ojediran, J.O.; Okonkwo, C.E.; Adeyi, A.J.; Adeyi, O.; Olaniran, A.F.; George, N.E.; Olayanju, T.M.A. Drying characteristics of yam slices (Dioscorea rotundata) in a convective hot air dryer: Application of ANFIS in the prediction of drying kinetics. Heliyon 2020, 6, e03555. [CrossRef]

28. Maleki, M.; Shahidi, F.; Varidi, M.J.; Azarpazhooh, E. Hot air drying kinetics of novel functional carrot snack: Impregnated using polyphenolic rich osmotic solution with ultrasound pretreatment. J. Food Process Eng. 2019, 43, 13331. [CrossRef]

29. Motevali, A.; Hedayati, F. Investigation of change drying rate constant coefficient in simulations models with various pretreatments on drying apple. J. Innov. Food Technol. 2017, 4, 39-51.

30. Taghinezhad, E.; Kaveh, M.; Khalife, E.; Chen, G. Drying of organic blackberry in combined hot air-infrared dryer with ultrasound pretreatment. Dry. Technol. 2020, 2020, 1-17. [CrossRef]

31. Abano, E.E. Microwave and blanching pretreatments for hot air drying of orange-fleshed sweet potato slices (Ipomoea batatas). Int. J. Food Sci. 2020, 2020, 1-12. [CrossRef] [PubMed]

32. Motevali, A.; Minaei, S.; Banakar, A.; Ghobadian, B.; Khoshtaghaza, M.H. Comparison of energy parameters in various dryers. Energy Convers. Manag. 2014, 87, 711-725. [CrossRef]

33. Abbaspour-Gilandeh, Y.; Kaveh, M.; Fatemi, H.; Hernández-Hernández, J.L.; Fuentes-Penna, A.; Hernández-Hernández, M. Evaluation of the changes in thermal, qualitative, and antioxidant properties of terebinth (Pistacia atlantica) fruit under different drying methods. Agronomy 2020, 10, 1378. [CrossRef]

34. Motevali, A.; Hashemi, S.J.; Taghinejad, E. Investigation of energy parameters, environment and social costs for drying process (Case study: Apple slices). Agr. Mechan. Sys. Res. 2019, 20, 37-54.

35. Song, Y.; Tao, Y.; Zhu, X.; Han, Y.; Show, P.L.; Song, C.; Zaid, H.F.M. Ultrasound-enhanced hot air drying of germinated highland barley seeds: Drying characteristics, microstructure, and bioactive profile. AgriEngineering 2019, 1, 496-510. [CrossRef]

36. Dehghannya, J.; Bozorghi, S.; Heshmati, M.K. Low temperature hot air drying of potato cubes subjected to osmotic dehydration and intermittent microwave: Drying kinetics, energy consumption and product quality indexes. Heat Mass Transf. 2018, 54, 929-954. [CrossRef]

37. Abbaspour-Gilandeh, Y.; Kaveh, M.; Aziz, M. Ultrasonic-microwave and infrared assisted convective drying of carrot: Drying kinetic, quality and energy consumption. Appl. Sci. 2020, 10, 6309. [CrossRef]

38. Motevali, A.; Zabihnia, F. Effect of the different pre-treatments thermal, pulse, chemical and mechanical on the external mass transfer coefficient changes, moisture diffusion coefficient and activation energy. J. Res. Innov. Food Sci. Tech. 2017, 6, 227-290.

39. Taghinezhad, E.; Kaveh, M. Modeling and Optimization of Specific Energy Consumption and Green House Gas Emissions During Drying of Organic Blackberry with Different Pretreatments by Response Surface Methodology. IR. J. Biosys. Eng. 2020, 51, 351-369.

40. Barani, Y.H.; Zhang, M.; Wang, B. Effect of thermal and ultrasonic pretreatment on enzyme inactivation, color, phenolics and flavonoids contents of infrared freeze-dried rose flower. J. Food Meas. Charact. 2020, 1-10. [CrossRef]

41. Gharehbeglou, P.; Askari, B.; Rad, A.H.; Hoseini, S.S.; Pour, H.T.; Rad, A.H.E. Investigating of drying kinetics and mathematical modeling of turnip. Agric. Eng. Int. CIGR J. 2014, 16, 194-204.

42. Adedeji, A.A.; Gachovska, T.K.; Ngadi, M.; Raghavan, G.S.V. Effect of pretreatments on drying characteristics of okra. Dry. Technol. 2008, 26, 1251-1256. [CrossRef]

43. Taghinezhad, E.; Kaveh, M.; Jahanbakhshi, A.; Golpour, I. Use of artificial intelligence for the estimation of effective moisture diffusivity, specific energy consumption, color and shrinkage in quince drying. J. Food Process Eng. 2020, 43, 13358. [CrossRef]

44. Forouzanfar, A.; Hojjati, M.; Noshad, M.; Szumny, A. Influence of UV-B pretreatments on kinetics of convective hot air drying and physical parameters of mushrooms (Agaricus bisporus). Agriculture 2020, 10, 371. [CrossRef]

45. Horuz, E.; Bozkurt, H.; Karataş, H.; Maskan, M. Comparison of quality, bioactive compounds, textural and sensorial properties of hybrid and convection-dried apricots. J. Food Meas. Charact. 2017, 12, 243-256. [CrossRef]

46. Shi, Y.; Chen, G.; Chen, K.; Chen, X.; Hong, Q.; Kan, J. Assessment of fresh star anise (Illicium verum Hook.f.) drying methods for influencing drying characteristics, color, flavor, volatile oil and shikimic acid. Food Chem. 2021, 342, 128359. [CrossRef]

47. Chayjan, R.A.; Kaveh, M.; Dibagar, N.; Nejad, M.Z. Optimization of pistachio nut drying in a fluidized bed dryer with microwave pretreatment applying response surface methodology. Chem. Prod. Process Model. 2017, 12. [CrossRef] 